\title{
GMR
}

\section{Genetic analysis of five sedentary fish species in middle Laranjinha River (upper Paraná River basin): A case study}

\author{
W. Frantine-Silva', D.G. Ferreira', R.H.C. Nascimento', J.F. \\ Fracasso $^{1}$, J.E. Conte ${ }^{2}$, F.P. Ramos ${ }^{1}$, S. Carvalho ${ }^{2}$ and B.A. Galindo ${ }^{1}$ \\ 1 Universidade Estadual do Norte do Paraná, \\ Campus de Cornélio Procópio, Cornélio Procópio, PR, Brasil \\ 2Universidade Estadual do Norte do Paraná, \\ Campus Luiz Meneghel, Bandeirantes, PR, Brasil \\ Corresponding author: W. Frantine-Silva \\ E-mail: wilsonfrantine@gmail.com
}

Genet. Mol. Res. 14 (4): 18637-18649 (2015)

Received August 9, 2015

Accepted October 18, 2015

Published December 28, 2015

DOI http://dx.doi.org/10.4238/2015.December.28.13

\begin{abstract}
Most studies of diversity and genetic structure in neotropical fish have focused on commercial species from large rivers or their reservoirs. However, smaller tributaries have been identified as an important alternative migratory route, with independent pools of genetic diversity. In this context, the present study aimed to evaluate genetic diversity and structure in five neotropical fish species from a region of Laranjinha River in the upper Paraná River basin. PCR-RAPD (random amplified polymorphic DNA) markers were used to characterize around 40 individuals of each species distributed upstream and downstream of Corredeira Dam that interrupts the river. The descriptive index of genetic diversity $\left(P=30.5-82 \% ; H_{E} 0.122-0.312\right)$ showed that the populations have acceptable levels of genetic diversity. The values for Nei's genetic distance $\left(D_{N} \min 0.0110\right.$ and max 0.0306$)$ as well as the genetic structure index and the analysis of molecular variance (AMOVA,
\end{abstract}


$\phi_{\mathrm{ST}} \min 0.0132$ and $\max 0.0385$ ) demonstrated low, but significant levels of genetic structure. Bayesian analysis of assignment found two $k$ clusters, including several individuals with mixed ancestry for all populations from the five species analyzed. These findings along with historical data on rainfall and the low dimensions of the dam studied here support the hypothesis that periodic floods enable the transit of individuals between different localities mitigating the differentiation process between populations.

Key words: RAPD; Sedentary species; Genetic diversity; Neotropical fish

\section{INTRODUCTION}

Hydroelectric dams are among the leading causes of loss of diversity in Brazilian freshwater ecosystems, mainly as a result of changes to environmental features and alterations of river flow (Agostinho et al., 2008). These changes influence the reproduction, distribution, and vulnerability of populations to stochastic processes related to loss of genetic diversity (Slatkin, 1985; Piorski et al., 2008; Oliveira et al., 2009). The upper Paraná River basin is one of the most studied watersheds in South America. However, most studies have concentrated on the larger rivers, thus limiting our knowledge about fish fauna in smaller tributaries (Castro et al., 2002; Galves et al., 2009). The Laranjinha River is the main tributary of the Cinzas river basin; together, these two rivers have retained the last lotic conditions in the Capivara Reservoir, Paranapanema River (Hoffmann et al., 2005), following construction of the Mauá hydropower plant (HPP) in the middle stretch of the Tibagi river (completed in 2013) and the Canoas HPP Complex (completed in 1998), which is located close upstream of the Cinzas river mouth. In the late 1950s, a small hydroelectric center was built in the middle part of the Laranjinha River, fragmenting and altering the natural features of this environment. Subsequently a fish ladder was built in 2006 aiming to restore the fish migratory flow.

Several studies have indicated that the Cinzas River basin is a strategic point for ichthyofauna conservation, mainly because of the great diversity in its fish fauna (Hoffman et al., 2005). This basin has also been identified as the last migratory route free of significant barriers to fish of the Capivara Reservoir, providing a reproductive shelter for local ichthyofauna (Vianna and Nogueira, 2008). However, despite its importance, there are currently several projects that aim to build further hydropower plants in this basin. For this reason, monitoring the genetic diversity levels and their distribution throughout the basin are of paramount importance for species conservation. Furthermore, such information can be very helpful in understanding the effects of anthropogenic activities, such as dams, on the fish populations throughout the river basin. In the last decade, use of PCR-RAPD (random amplified polymorphic DNA) markers has been widely adopted to study genetic diversity and structure in neotropical fish populations in South America (Piorski et al., 2008), producing results that are comparable with those from other markers (Ramos et al., 2008; Muneer et al., 2009; Phong et al., 2011).

The aim of the present study was to analyze the structure and genetic diversity in five fish species with short or no reproductive displacement: Astyanax altiparanae Garutti and Britisk, 2000, Leporinus amblyrhynchus Garavello and Britski, 1987, Leporinus octofasciatus Steindachner, 
1915, Pimelodus microstoma Steindachner, 1877, and Steindachnerina insculpta (FernándezYépez, 1948). The fish were collected both upstream and downstream of the Corredeira Dam on the Laranjinha river with the sampling designed to show the effects of damming activities on the structure and genetic diversity of the local ichthyofauna.

\section{MATERIAL AND METHODS}

\section{Study area and sampling}

The course of the Laranjinha River is all within the Paraná state, with its source in Ventania

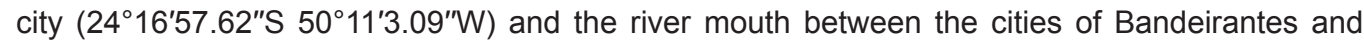
Santa Mariana $\left(23^{\circ} 1^{\prime} 53.90^{\prime \prime} \mathrm{S}, 50^{\circ} 26^{\prime} 51.90^{\prime \prime} \mathrm{W}\right)$. The average width of the river is $65 \mathrm{~m}$ with an approximate length of $350 \mathrm{~km}$ including the bends and $250 \mathrm{~km}$ straight, running in a northwest direction from the headwater to the mouth (Figure 1).

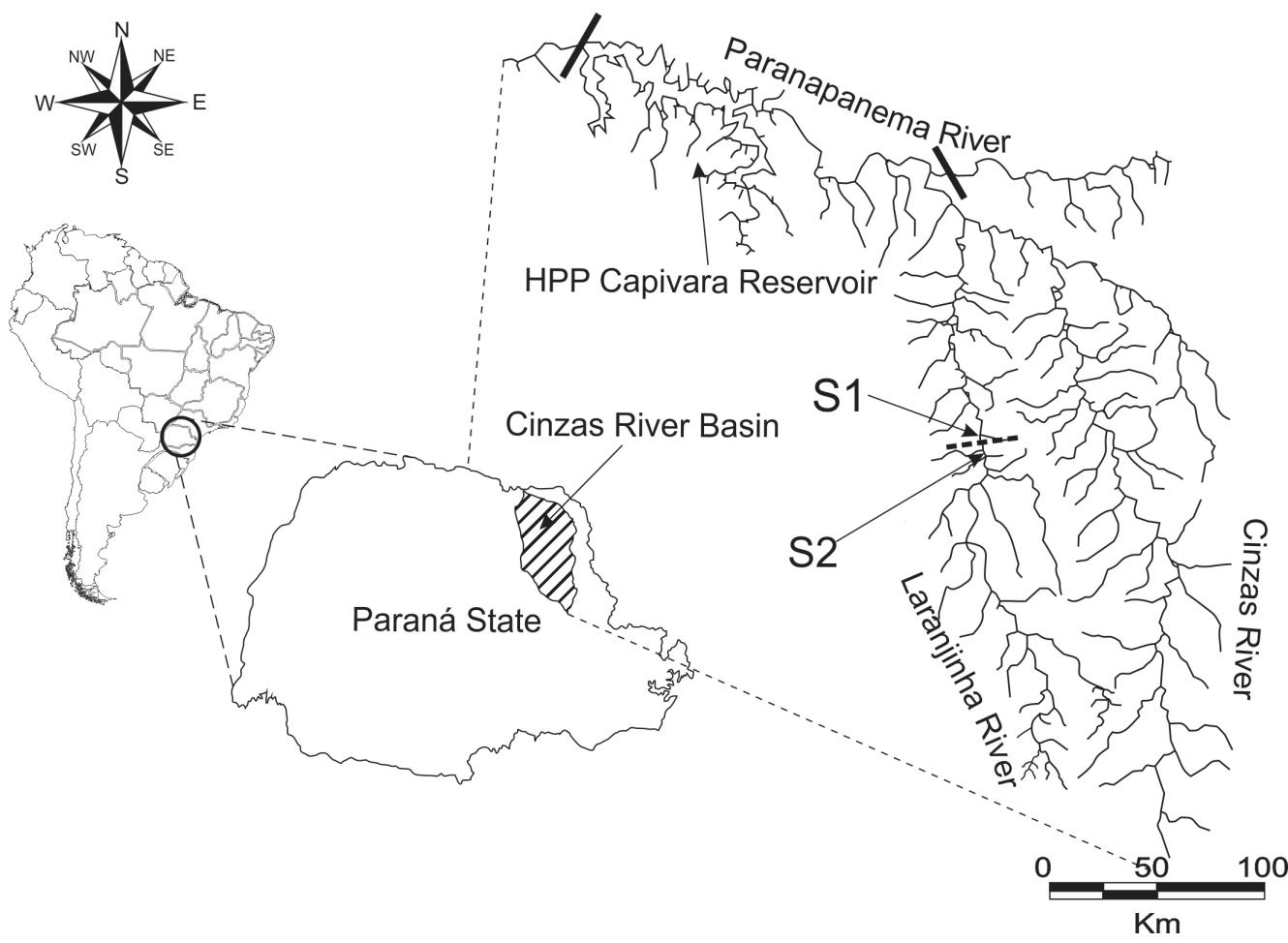

Figure 1. Map showing location of the sampling stations. The dashed line over the Laranjinha River indicates the Corredeira Dam; the solid lines over the Paranapanema River show the Capivara Dam (left) and Canoas I Dam (right); S1 and S2 respectively indicate upstream and downstream sampling sites relative to the dam. Cartography source: IPARDES -1995 and IAP -1997, edited by the authors.

Corredeira Dam is located $97.31 \mathrm{~km}$ from the river mouth, and lies between Ribeirão

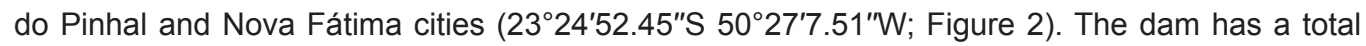


length of $97 \mathrm{~m}$ and approximated height of $4.9 \mathrm{~m}$. The upstream reservoir is $4.3 \mathrm{~km}$ in length and has an average width of $65.35 \mathrm{~m}$. Sampling was performed from February 2009 to January 2010. To catch the fish, $1530 \mathrm{~m}^{2}$ of nets with mesh-size of 20 to $180 \mathrm{~mm}$ between opposite nodes were used. Identical nets were used in the two sampling sites. Biological samples were removed from collected individuals and stored in $70 \%$ ethanol at $-20^{\circ} \mathrm{C}$.

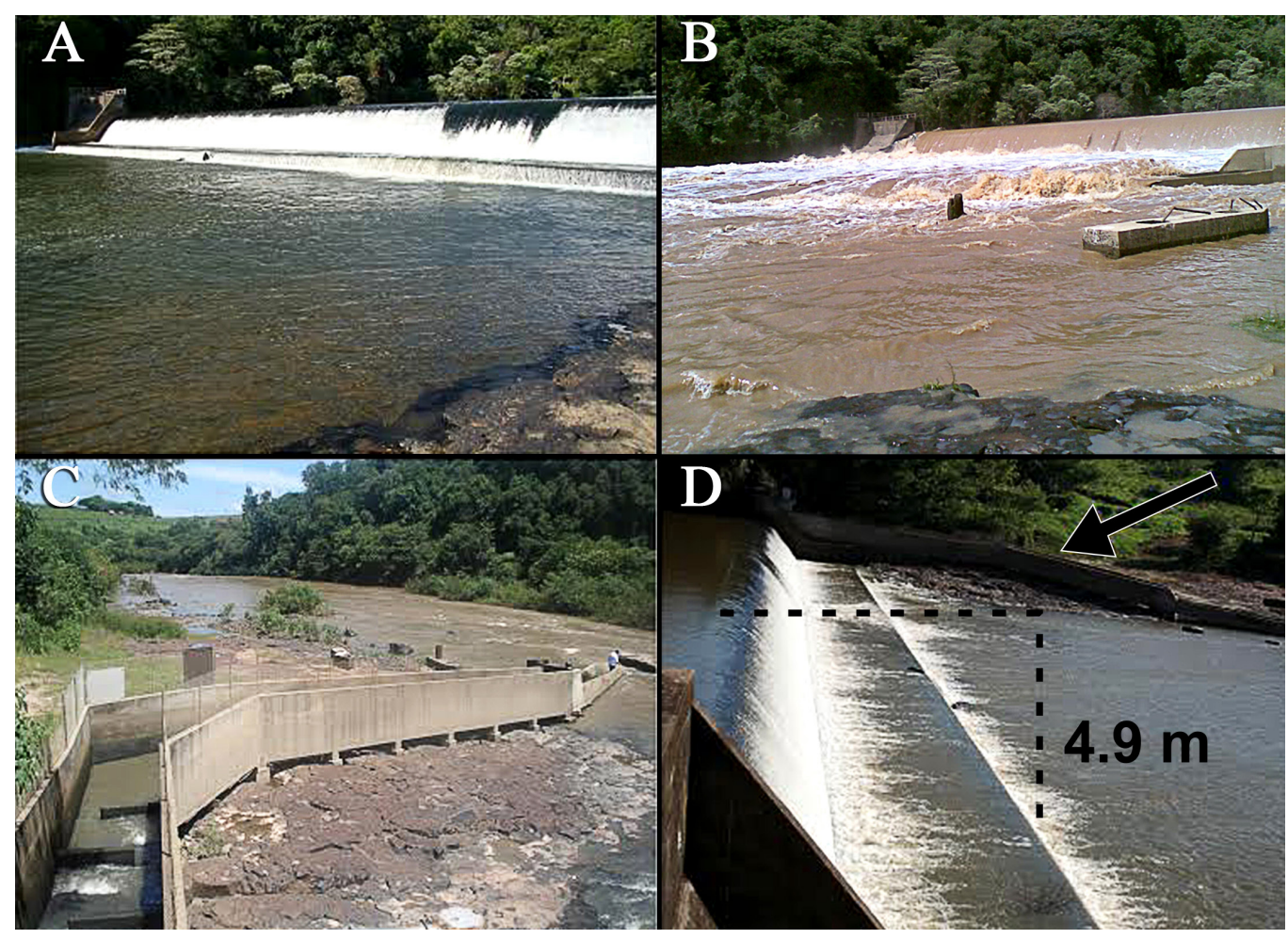

Figure 2. Partial view of the collection sites on the Laranjinha River, Paraná - Brazil: (A) Downstream from Corredeira Dam in dry season. (B) Downstream from Corredeira Dam in wet station. (C) Fish ladder from upstream view in dry station. (D) Reverse view of Corredeira Dam in dry station. Black arrow indicates the fish ladder.

\section{DNA extraction and PCR-RAPD}

Genomic DNA was extracted by an $\mathrm{NaCl}$ protocol (Bardakci and Skibinski, 1994) and then placed in $30 \mu \mathrm{L}$ TE buffer (0.5 M Tris-EDTA). The samples were quantified using a fluorimeter (Qubit - Life Technologies, Grand Island, NY, USA) and diluted to $5 \mathrm{ng} / \mu \mathrm{L}$. Initially, 20 primers were tested for each species. Only those primers, which produced good electrophoretic patterns with consistently high staining intensities and numbers of fragments were selected for the analyses. PCR was performed in a final volume of $15 \mu \mathrm{L}$ that contained $15 \mathrm{ng}$ DNA, $1 \mathrm{U}$ Taq Polymerase (Invitrogen), 1X supplied buffer reaction, $3.3 \mathrm{mM} \mathrm{MgCl}_{2}, 250 \mu \mathrm{M}$ dNTP (Amresco), $0.33 \mu \mathrm{M}$ primer, 
and bidistilled water to volume. Negative controls were performed for all reactions with the same components except substitution of DNA with water. All reactions were subjected to quality control and only reproducible electrophoretic patterns were analyzed.

Amplification was performed in a Peltier Thermo-cycler PCT-100 with the following program: $4 \mathrm{~min}$ at $96^{\circ} \mathrm{C}$; 40 cycles of $40 \mathrm{~s}$ at $92^{\circ} \mathrm{C}, 1.5 \mathrm{~min}$ at $40^{\circ} \mathrm{C}$ and $2 \mathrm{~min}$ at $72^{\circ} \mathrm{C}$; with a final extension of $5 \mathrm{~min}$ at $72^{\circ} \mathrm{C}$. The PCR products were separated by electrophoresis on a $1.4 \%$ agarose gel (0.89 $\mathrm{M}$ Tris, $1 \mathrm{mM}$ EDTA, $0.89 \mathrm{M}$ boric acid, $\mathrm{pH} 8.3)$ run at $3 \mathrm{~V} / \mathrm{cm}$, and visualized by ethidium bromide staining and UV illumination.

\section{Genetics and statistical analysis}

The PCR-RAPD technique identifies dominant markers and thus is considered a di-allelic system in the present study in which only one of two alleles at a locus can be amplified by PCR. Statistical methods developed for analysis of data from codominant markers have been adapted for use with PCR-RAPD markers (Lynch and Milligan, 1994). Electrophoretic patterns were determined by direct comparison between individuals. Each band was analyzed as a binary variant, either present or absent, and then was transcribed to a binary matrix for computational analysis.

The software Dboot v1.1 (Coelho, 2001) was used to determine the degree of variance in the data, based on the number of loci analyzed, through the bootstrap method. Only samples with a degree of variance less than $5 \%$ were included in the analysis. The program TFPGA v1.3 (Miller, 1997) was employed for the following analyses: genetic distance (DN) and average expected heterozygosity (HE), as described by Nei (1978), and the proportion of polymorphic loci $(P)$ with a threshold of $95 \%$. Structure v.2.3.4 software (Pritchard et al., 2000) was used to evaluate the relationship between samples from Bayesian clusters, with parameters according to Ferreira et al. (2014). The Arlequin v 3.0 program (Excoffier et al., 2005) was used to perform F-statistics (Wright, 1978) and AMOVA analysis (Excoffier et al., 1992). AMOVA significance was verified through 1000 bootstrap replications and 10,000 bootstraps to F-statistics. The genetic variation between groups was analyzed according to Wright (1978) and indicated by Excoffier et al. (1992), where $\phi S T$ values up to 0.05 indicate low genetic structure, 0.05 to 0.15 moderate structure, 0.15 to 0.25 indicate high genetic structure, and values greater than 0.25 indicate very high genetic structure. The $\phi S T / F S T$ values were submitted to a statistical test with P-values less than 0.05 regarded as non-significant.

River depth data were provided by Agência Nacional de Águas (ANA) through the historical record held at the Hydrological System Information HidroWeb (available at: http://hidroweb.ana. gov.br/, accessed on 19/01/2013). All available measurements from the Santa Teresa hydrometric

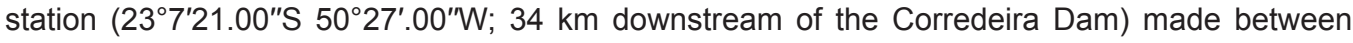
1970 and 2010 were included to calculate the average monthly depth variation in the Laranjinha River over the last 40 years.

\section{RESULTS}

An average of 150 loci (range 121-177) was analyzed for each species. The degree of variance in the data showed values of lower than $5 \%$ for all species. The primers and total number 
of loci for each species are listed in Table 1.

\begin{tabular}{|c|c|c|}
\hline Specie & Primers & $\mathrm{N}_{\mathrm{L}}$ \\
\hline A. altiparanae & A7, A10, D8, D10, D11, D18, P6 & 145 \\
\hline L. amblyrhynchus & A3, A7, D2, D8, D10, D11, D13, D18, W11 & 121 \\
\hline L. octofaciatus & A13, A19, D2, D3, D8, D10, D13, D16, D18 & 177 \\
\hline P. microstoma & A4, A7, B6, D2, D3, D10, D11, D18 & 153 \\
\hline S. insculpta & A2, A7, B5, B1, D3, D8, L14, L13, O15, W1, W4, W7, W8, W9 & 163 \\
\hline
\end{tabular}

The parameters of genetic diversity, $\mathrm{P}$ and $H_{\mathrm{E}}$, showed low variation between populations of all species, indicating that the populations sampled upstream and downstream of the dam showed similar levels of genetic diversity. The highest values were observed in $A$. altiparanae $(\mathrm{P}=$ $82.0 \%$, and $77 \% ; H_{E}=0.312$ and 0.309 ), for downstream and upstream populations respectively. L. amblyrhynchus showed the lowest values $(P=34.7$ and $30.5 \%)$ and $H_{E}=0.122$ and 0.124$)$ downstream and upstream, respectively (Table 2).

Table 2. Index for genetic distance, genetic diversity, molecular variance and genetic structuring.

\begin{tabular}{|c|c|c|c|c|c|c|c|c|c|c|c|}
\hline \multirow[t]{2}{*}{ Specie } & \multicolumn{3}{|c|}{$\mathrm{N}$} & \multicolumn{2}{|c|}{$\overline{\mathrm{P}}_{\%}$} & \multicolumn{2}{|c|}{$\bar{H}_{\mathrm{E}}$} & \multirow[t]{2}{*}{$\phi_{\mathrm{ST}}$} & \multirow[t]{2}{*}{$D_{N}$} & \multicolumn{2}{|c|}{ AMOVA } \\
\hline & $\mathrm{S} 1$ & S2 & $\mathrm{T}$ & $\mathrm{S} 1$ & $\mathrm{~S} 2$ & $\mathrm{~S} 1$ & $\mathrm{~S} 2$ & & & WP & BP \\
\hline A. altiparanae & 21 & 22 & 43 & 82.0 & 77.2 & 0.312 & 0.309 & $0.0385^{\star *}$ & 0.0154 & 96.14 & 3.86 \\
\hline L. amblyrhynchus & 22 & 21 & 43 & 34.7 & 30.5 & 0.122 & 0.124 & $0.0257^{\star}$ & 0.0110 & 97.42 & 2.58 \\
\hline L. octofasciatus & 19 & 22 & 41 & 64.9 & 60.4 & 0.238 & 0.226 & $0.0234^{* *}$ & 0.0114 & 97.66 & 2.34 \\
\hline P. microstoma & 20 & 24 & 44 & 76.4 & 75.1 & 0.288 & 0.290 & $0.0259^{\star *}$ & 0.0306 & 97.41 & 2.59 \\
\hline S. insculpta & 22 & 21 & 43 & 46.6 & 47.2 & 0.164 & 0.168 & 0.0132 & 0.0113 & 98.68 & 1.32 \\
\hline
\end{tabular}

$\mathrm{N}=$ number of samples for each species. $\mathrm{S} 1=$ downstream sample site; $\mathrm{S} 2=$ upstream sample site; $\mathrm{T}=$ results for all individuals; $\mathrm{D}_{\mathrm{N}}=$ unbiased Ney's genetic distance; $\overline{\mathrm{P}}=$ proportion of poliforphic loci; $\bar{H}_{\mathrm{E}}=$ average of expected heterozygosity; $\phi_{\mathrm{ST}}=$ structure index; $\mathrm{AMOVA}$ : $\mathrm{WP}=$ within; $\mathrm{BP}=$ between populations. ${ }^{*} \mathrm{P}<0,05 ;{ }^{* *} \mathrm{P}<0,001$.

The values of $\phi_{\mathrm{ST}}$ differed significantly between populations downstream and upstream of the dam in four of the five species. A. altiparanae had the highest value between populations (0.0385), while S. insculpta had the lowest value (0.0132) and was not significant $(\alpha=5 \%)$. Nei's unbiased genetic distance ranged from 0.0110 to 0.306 for populations of $L$. amblyrhynchus and $P$. microstoma, respectively. For all species, AMOVA showed the greatest variation within populations $(96.14-98.61 \%)$ rather than between populations (Table 2).

The STRUCTURE analysis (Bayesian inference of clusters), run on a daset of the five species, showed two clusters as the most probable $K$ value calculated from delta $K(\Delta \mathrm{K})$ for all species (Figure 3 ). The analysis shows two groups with apparently some mixture between the groups. Individual assignments showed the presence of several individuals with variable levels of mixed ancestry distributed between the sampled locations. Only $A$. altiparanae 
showed a higher proportion of individuals from the same cluster at the downstream sampling site.
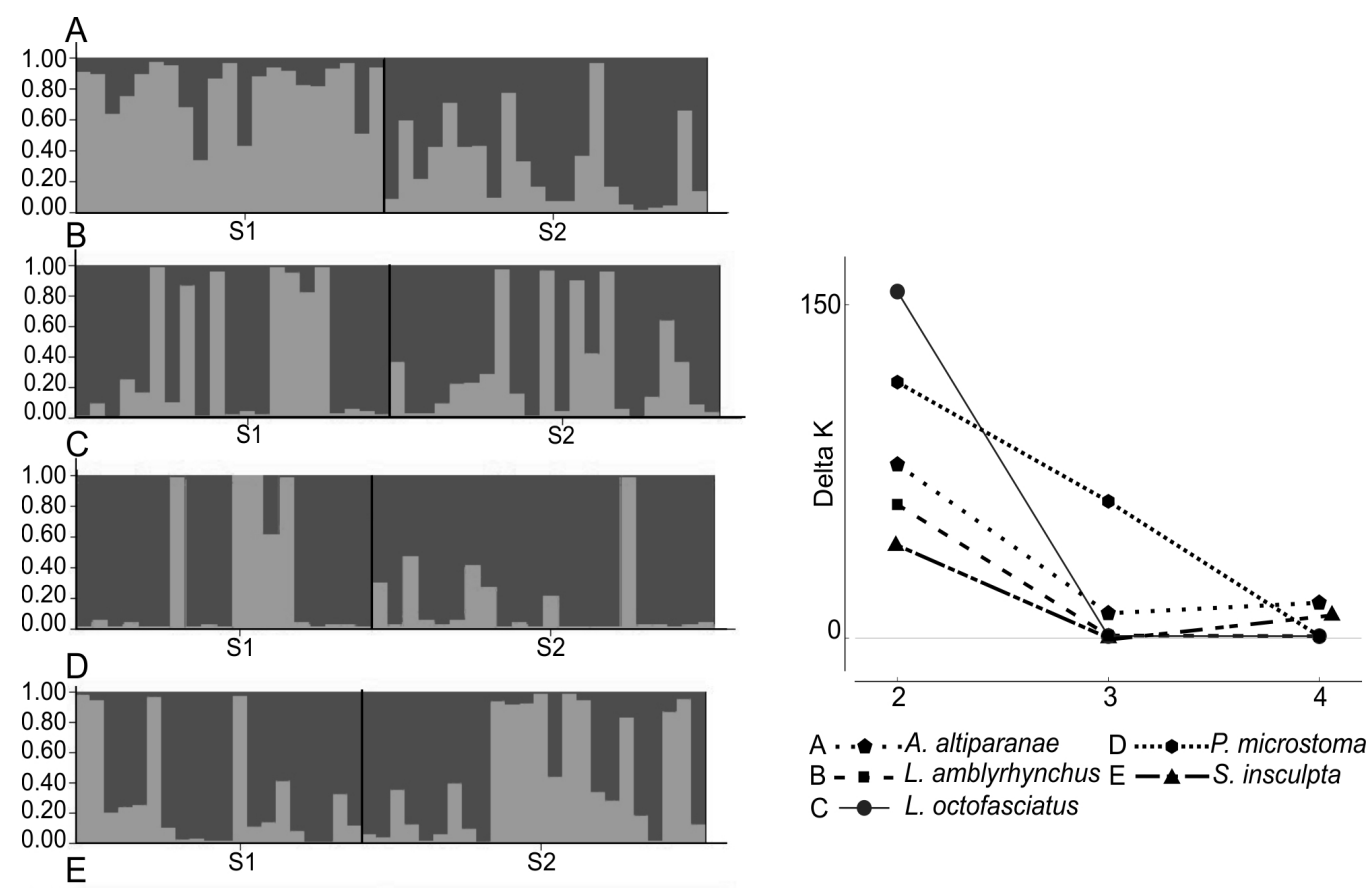

A .... A. altiparanae D ........P. microstoma B - - - L. amblyrhynchus E - $\mathbf{-}$-S. insculpta $\mathrm{C} \rightarrow$ L. octofasciatus

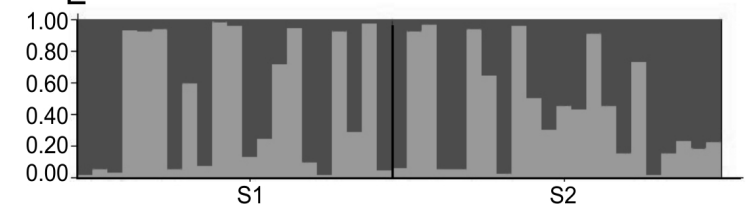

Figure 3. Result of the STRUCTURE analysis for five species from the Laranjinha River. A. Astyanax altiparanae. B. Leporinus amblyrhynchus. C. Leporinus octofasciatus. D. Pimelodus microstoma. E. Steindachnerina insculpta. All graphical representations were based on $K=2$. Colors represent the probability membership coefficient of that individual (column) for each genetic cluster. RAPD data plots are estimates of $K$ group numbers based on the delta $K$ statistic (Evanno et al., 2005). S1, Individuals from the upstream site; S2, individuals from the downstream site.

We obtained the records of average depth of the Laranjinha River at the Santa Teresa hydrometric station (downstream of Corredeira Dam) and examined the period from October 1970 to November of 2010. The monthly average depth was calculated and found to range between 0.88 and $5.68 \mathrm{~m}$ (Figure 4). The historical series showed seven occasions when the level of the river was greater than the dam height and eight other occasions when river level was less than 1 $\mathrm{m}$ below maximum dam height $(4.9 \mathrm{~m})$. 


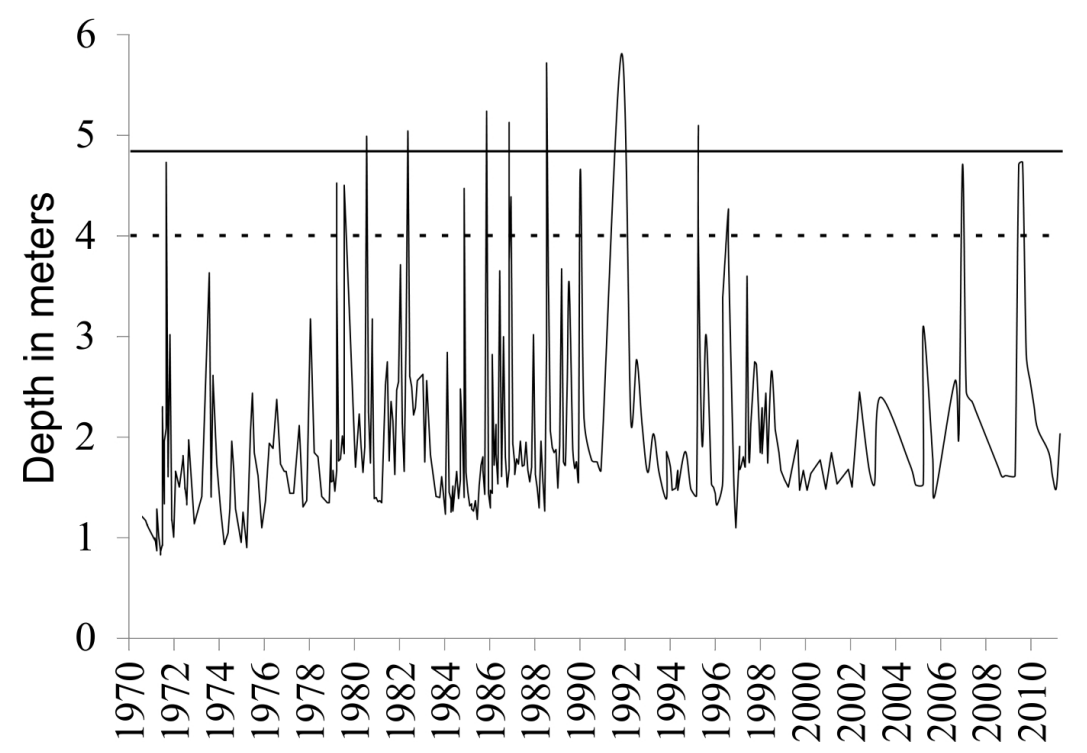

Figure 4. Average depth of the Laranjinha River between 1970 and 2010 measured at Santa Teresa Station $\left(23^{\circ}\right.$ $\left.7^{\prime} 21.00^{\prime \prime} 50^{\circ} 27^{\prime} 1.00 " \mathrm{~W}\right)$. Solid line shows the height of the Corredeira Dam (4.9 m); dashed line indicates a reference line of four meters. Data from Agência Nacional de Águas (ANA).

\section{DISCUSSION}

RAPD markers have been used for analysis of genetic diversity and structure in freshwater fish species (Piorski et al., 2008). Despite the limitations of the technique, prudent application of these markers can provide equivalent results and interpretations to those derived from codominant marker analysis (Ramos et al., 2008, 2012; Phong et al., 2011). Moreover, the results produced by RAPD markers are reproducible (Pascual et al., 2006).

Genetic diversity studies in neotropical ichthyofauna have focused on species with a long history of reproductive displacement (Piorski et al., 2008; Oliveira et al., 2009). The effects on these species are often related to the immediate impacts of the construction of dams, which often affect migration routes and, therefore, gene flow within and between populations. However, because of the high genetic diversity of these species before fragmentation (Ramos et al., 2012; Sanches et al., 2012) and their migratory capacity (Agostinho et al., 2003), the processes that drive genetic structure evolution after fragmentation, such as genetic drift and inbreeding, may be attenuated in the short and medium term. The dispersion capacity of migratory species can support the maintenance of large groups of interbreeding individuals even when the fish are absent from intermediate stretches in the river. Populations of migratory fish species can also introduce a bias into the analysis of genetic structure patterns due the historical accumulation of different levels of genetic structure associated with homing behavior or migratory waves (Hatanaka et al., 2006; Sanches and Galetti Jr., 2012; Sanches et al., 2012), making it difficult to determine whether variations in genetic structure are due to fragmentation. Although studies on migratory species are important, their intrinsic biological features hamper extending the conclusions to species that do not migrate. The present study is one of the few to analyze genetic structure in populations of 
small fish with short or no reproductive displacement, with the aim of characterizing the effects of fragmentation in resident populations.

The results presented here indicate that the groups sampled at both study sites showed acceptable levels of genetic diversity, in agreement with previous investigations of these species (see Table 2). Previous studies using RAPD reported the following values of $\overline{\mathrm{P}}$ : Schizodon intermedius 45.5\%, Schizodon nasutus $41.4 \%$, Leporinus amblyrhynchus $29.3 \%$, Leporinus friderici $46.3 \%$, Leporinus striatus $41 \%$, Leporinus octofasciatus $55.1 \%$, Leporinus elongatus $58.7 \%$, and Leporinus obtusidens 53.1\% (Chiari and Sodré, 2001); Astyanax altiparanae $78.41 \%$ (Leuzzi et al., 2004), Astyanax aff. bimaculatus 85.71\% (Pamponet et al. 2008), Pimelodus maculatus 50.1$60.94 \%$ (Almeida et al., 2003), and Steindachnerina insculpta 76.6\% (Oliveira et al., 2002). By comparison, we found $\bar{P}$ values of $82.0 \%$ to $30.5 \%$, and $H_{E}$ levels of 0.312 to 0.122 in the five species studied here. The highest $\overline{\mathrm{P}}$ and $H_{\mathrm{E}}$ values were observed in $A$. altiparanae and the lowest values in $L$. amblyrhynchus (Table 2). All levels of genetic diversity in the populations studied here were evaluated as satisfactory compared to previously reported data (Chiari and Sodré, 2001; Almeida et al., 2003; Leuzzi et al., 2004; Pamponet et al., 2008).

Nei's genetic distance estimates the sharing of molecular phenotypes; complete sharing is indicated by a score of zero, while no sharing is reflected by infinite values of genetic distance (Nei, 1978). The estimates of genetic distance $\left(D_{N}\right)$ observed here did not exceed the threshold of 0.015 (Table 2), indicating a low level of genetic distance between samples upstream and downstream of the dam. Other studies found genetic distance values higher than here and considered these values to indicate low levels of genetic differentiation. Populations of Astyanax altiparanae studied by Leuzzi et al. (2004) gave genetic distance estimates close to 0.12 in an area without geographical barriers; Sofia et al. (2006) found higher levels of genetic distance (approximately 0.61) for Astyanax scabripinnis.

The estimates of genetic structure within and between populations are indicative of the levels of diversity and differentiation and they are therefore of great value for studies on species conservation. F statistics (Wright, 1978) or their analogs are measurements of the hierarchical levels of structure within and between populations (Piorski et al., 2008; Oliveira et al., 2009). In the present study, relatively low levels of genetic structure, i.e., $F_{\mathrm{ST}} / \phi_{\mathrm{ST}}$ values smaller than 0.05 (Wright, 1978; Excoffier et al., 1992), were found in four species but not S. insculpta (Table 2). Only S. insculpta showed $\mathrm{P}>0.05$ indicating that the null hypothesis of panmixia cannot be refuted.

Several studies have shown variations in genetic structure in neotropical fish populations due to isolation by distance in non-migratory species (Leuzzi et al., 2004; Sofia et al., 2006; Pamponet et al., 2008) or by formation of demes influenced by biological factors in species with a migratory habit (Wasko and Galetti Jr., 2002; Hatanaka and Galetti Jr., 2003). In neotropical fish populations fragmented by dams, there is a tendency towards changes in genetic structure when gene flow is disrupted. Significant genetic structure differences were found between populations of Pimelodus maculatus fragmented by dams in Paranapanema (Almeida et al., 2003), suggesting that this fragmentation has increased the rate of differentiation, which was initially caused by the existence of several natural waterfalls. Pamponet et al. (2008) also found significant genetic structure differences between populations of Astyanax aff. bimaculatus in southeast Bahia that were separated by dams. The authors report that the levels of genetic structure among fragmented populations were as high those among populations living in adjacent watersheds. This finding is in contrast to the present study that found a low level of genetic structure between upstream and downstream populations. 
AMOVA is a means to analyze genetic diversity partition in natural populations (Meirmans, 2006). The interpretation of this analysis directly reflects the population structure; if the major part of variance is shared, then the populations tend to less difference; if the variance is not shared, then the populations tend to show increased differences (Excoffier et al., 1992). In the present study, we found that the variance within populations was always greater than the variance between them (>96\%; Table 2). Sofia et al. (2008) studied the sedentary species Hypostomus ancistroides and their AMOVA analysis of PCR-RAPD marker data gave within and among population values of 90.85 and $9.15 \%$, respectively. They also found molecular variance differences greater than $10 \%$ among contiguous sub-localities without physical barriers, agreeing with the high level of genetic structuring found for the same subpopulations $\left(\phi_{\mathrm{ST}} \cong 0.10\right)$. Similar results were reported by Ferreira et al. (2014) in an AFLP marker analysis of the sedentary species Geophagus brasiliensis in the Laranjinha River. Lopes et al. (2007) studied the migratory species Salminus brasiliensis and sampled at fish ladders of Canoas I, Canoas II, and Rio Paranapanema. They showed that the greater part of molecular variance (AMOVA) was found within groups ( 98\%) with low levels of structuring between different localities $\left(F_{\mathrm{ST}}=0.018\right)$. These results indicated that the different sampling groups constituted unique populations. The data on molecular variance were consistent with the results of our Bayesian analysis using STRUCTURE software, which showed that despite the existence of two possible genetic clusters in each species, several individuals were derived from a mixture of the two clusters, and that individuals from the two clusters were present in both study sites (Figure 3). Similar patterns were also reported by Ferreira et al. (2014) using AFLP and SSR markers in G. brasiliensis from sites close to those sampled in present study.

Although the documented fragmentation time of the study region was around 50 years, the data presented here showed a low level of differentiation relative to measured genetic parameters between samples from upstream and downstream of the dams. Among the factors that might cause such low differentiation is the presence of a ladder built in 2006 that could facilitate gene flow. However, although we have not examined the effect of this fish ladder, observations made here indicated that only $P$. microstoma of the studied species was captured in the fish ladder. Additionally, the fish ladder was built relatively recently. Several studies have demonstrated the inefficiency and selectivity of fish ladders in Brazil (Agostinho et al., 2007; Agostinho et al., 2008). Considering the genetic similarity between the fish sampled upstream and downstream of the Corredeira Dam, and that only $P$. microstoma was captured in the fish ladder, other factors must influence the maintenance of gene flow. Most studies on population genetic structure in neotropical freshwater fish focus on the effects of large dams (Oliveira et al., 2009). Large geographic barriers tend to impose greater difficulties on fish movements and may result in complete interruption of gene flow (Agostinho et al., 2008). However, the dam studied here has relatively small dimensions with approximate height of $4.9 \mathrm{~m}$ and a length of $97 \mathrm{~m}$ (Figure 1). The relatively small size of the dam, coupled with the specific geomorphological and climatic characteristics of the Laranjinha river basin may constitute a unique situation. The rocky slopes along the river course form a channel that facilitates the erosion of the rock walls. The rate of erosion is greater in valleys around the dam area and reduces the distance between river banks. Added to these geological characteristics, the region including the Laranjinha River has a well-defined rainy period with high rainfall; this rainy period coincides with the breeding period of most species in the Paranapanema River basin (Agostinho et al., 2004). These features provide conditions that allow the reduction of the gap between water levels above and below the dam through the flooding of the downstream dam region during the fish breeding season. 
Examination of the historical data on water levels showed that these occasionally approached or exceeded the height of the dam (Figure 4). Considering the data and the low gap between upstream and downstream water levels, flooding peaks could allow the transit of fish between the regions above and below the dam. According to Slatkin (1985), just one migrant per generation is sufficient to homogenize allele frequencies between two populations. All genetic parameters evaluated here suggest that the populations of the five species showed gene flow. Although the specific geological features of the Corredeira dam facilitates, the potential movement of the fish, the majority of dams built for hydroelectric purposes have a major impact on neotropical fish populations, particularly from the genetic viewpoint (Agostinho et al., 2004, 2007). However, until markers applicable to multi-allelic analyzes are used to confirm our speculation on the cause of gene flow, this conclusion should be treated with caution.

The data obtained in this study indicate that the fish populations upstream and downstream of the Corredeira dam cannot yet be considered as genetically differentiated. The results reveal a very particular and unusual situation affecting the populations separated by this particular physical barrier. It is likely that all five species are essentially single populations as a result of various factors including the geological characteristics, favorable weather conditions, and the large continuous areas above and below the dam without other large dams. These conditions certainly favored the maintenance of effective population sizes and could have delayed evolutionary processes that drive genetic differentiation. Additionally, our observations indicate that new dams on the Laranjinha River need be carefully evaluated because multiples factors affect these fish species. Our data suggest that natural flooding seems be important to the maintenance of some gene flow. Therefore, future dams on the river could break the natural flood regime. It is important to highlight that no operation of the dam since its construction has minimized the influence of this small hydropower plant over natural flooding in this river area. We suggest that other small hydropower plants on rivers with species with different degrees of migratory displacement should be conducted to assess genetic differentiation in other situations.

\section{Conflicts of interest}

The authors declare no conflict of interest.

\section{ACKNOWLEDGMENTS}

We thank the Instituto Ambiental do Paraná regional office of Cornélio Procópio-PR and the Municipality of Ribeirão do Pinhal-PR for logistical support; we also thank USIBAN, Fundação Araucária and UENP-CCP for financial support; Dr. Oscar A. Shibatta helped identify the specimens; the team of the Laboratório de Genética e Conservação (GECON) provided support during the collection and conduct of the work.

\section{REFERENCES}

Agostinho AA, Gomes LC, Suzuki HI and Julio Jr HF (2003). Migratory fishes of the Upper Paraná River basin, Brazil. In: Migratory fishes of South America: biology, fisheries and conservation status (Carolsfeld J, Harvey B, Ross CV and Baer A, eds.). The World Bank, International Development Research Centre, Ottawa, 19-98.

Agostinho AA, Thomaz SM and Gomes LC (2004). Threats for biodiversity in the floodplain of the Upper Paraná River : effects of hydrological regulation by dams. Ecohydrol. Hydrobiol. 4: 255-256. 
Agostinho AA, Pelicice FM and Gomes LC (2008). Dams and the fish fauna of the Neotropical region: impacts and management related to diversity and fisheries. Braz. J. Biol. 68: 1119-1132.

Agostinho CS, Agostinho AA, Pelicice FM, Almeida DA, et al. (2007). Selectivity of fish ladders: a bottleneck in Neotropical fish movement. Neotrop. Ichthyol. 5: 205-213.

Almeida FS, Sodré LMK and Contel EPB (2003). Population structure analysis of Pimelodus maculatus (Pisces, Siluriformes) from the Tietê and Paranapanema Rivers (Brazil). Genet. Mol. Biol. 26: 301-305.

Bardakci F and Skibinski DOF (1994). Application of the RAPD technique in tilapia fish: species and subspecies identification. Heredity 73: 117-123.

Castro RJ de, Nakatani K, Bialetzki A, Sanches PV, et al. (2002). Temporal distribution and composition of the ichthyoplankton from Leopoldo's Inlet on the Upper Parana River floodplain (Brazil). J. Zool. Lond. 256: 437-443.

Chiari L and Sodré LMK (2001). Study of eight species of the Anostomidae family (Pisces, Characiformes) by RAPD analysis. Acta Sci. Biol. 23: 445-451.

Coelho ASG (2001). DBOOT-Avaliação dos erros associados a estimativas de distâncias/similaridades genéticas através do procedimento de bootstrap com número variável de marcadores. Laboratório de Genética Vegetal, Instituto de Ciências biológicas, Universidade Federal de Goiás, Goiânia.

Evanno G, Regnaut S and Goudet J (2005). Detecting the number of clusters of individuals using the software STRUCTURE: a simulation study. Mol. Ecol. 14: 2611-2620

Excoffier L, Smouse PE and Quattro JM (1992). Analysis of molecular variance inferred from metric distances among DNA haplotypes: application to human mitochondrial DNA restriction data. Genetics 131: 479-491.

Excoffier L, Laval G and Schneider S (2005). Arlequin (version 3.0): An integrated software package for population genetics data analysis. Evol. Bioinform. Online 1: 47-50.

Ferreira DG, Galindo BA, Frantine-Silva W, Almeida FS, et al. (2014). Genetic structure of a Neotropical sedentary fish revealed by AFLP, microsatellite and mtDNA markers: a case study. Conserv. Genet. Avaliable at [http://link.springer. com/article/10.1007/s10592-014-0648-2].

Galves W, Shibatta OA and Jerep FC (2009). Estudos sobre diversidade de peixes da bacia do alto rio Paraná: uma revisão histórica. Semin. Cienc. Biol. Saud. 30: 141-154.

Hatanaka T and Galetti Jr PM (2003). RAPD markers indicate the occurrence of structured populations in a migratory freshwater fish species. Genet. Mol. Biol. 26: 19-25.

Hatanaka T, Henrique-Silva F and Galetti Jr PM (2006). Population substructuring in a migratory freshwater fish Prochilodus argenteus (Characiformes, Prochilodontidae) from the São Francisco River. Genetica 126: 153-159.

Hoffmann AC, Orsi ML, Shibatta OA, Biológicas PC, et al. (2005). Diversidade de peixes do reservatório da UHE Escola Engenharia Mackenzie (Capivara), Rio Paranapanema, bacia do alto rio Paraná, Brasil, e a importância dos grandes tributários na sua manutenção. Iheringia. Ser. Zool. 95: 319-325.

Leuzzi MSP, Almeida FS, Orsi ML and Sodré LMK (2004). Analysis by RAPD of the genetic structure of Astyanax altiparanae (Pisces, Characiformes) in reservoirs on the Paranapanema River, Brazil. Genet. Mol. Biol. 27: 355-362.

Lopes CM, Almeida FS, Orsi ML, Britto SGC, et al. (2007). Fish passage ladders from Canoas Complex-Paranapanema River : evaluation of genetic structure maintenance of Salminus brasiliensis (Teleostei: Characiformes). Neotrop. Ichthyol. 5: 131-138.

Lynch M and Milligan BG (1994). Analysis of population genetic structure with RAPD markers. Mol. Ecol. 3: 91-99.

Meirmans PG (2006). Using the AMOVA framework to estimate a standardized genetic differentiation measure. Evolution 60: 2399-2402.

Miller MP (1997). Tools for population genetic analyses (TFPGA): A Windows program for the analysis of allozyme and molecular population genetic data. Computer software distributed by author. Available at [http://www.marksgeneticsoftware.net/ tfpga.htm].

Muneer PMA, Gopalakrishnan A, Musammilu KK, Mohindra V, et al. (2009). Genetic variation and population structure of endemic yellow catfish, Horabagrus brachysoma (Bagridae) among three populations of Western Ghat region using RAPD and microsatellite markers. Mol. Biol. Rep. 36: 1779-1791.

Nei M (1978). Estimation of average heterozygosity and genetic distance from a small number of individuals. Genetics 89 : 583-590.

Oliveira C, Foresti F and Hilsdorf AWS (2009). Genetics of neotropical fish: from chromosomes to populations. Fish Physiol. Biochem. 35: 81-100.

Oliveira AV, Prioli AJ, Prioli SM, Pavanelli CS, et al. (2002). Diversity and genetic distance in populations of Steindachnerina in the upper Paraná river floodplain of Brazil. Genetica 115: 259-267.

Pascual AN, Suzuki KM, Almeida FS, Sodré LM, et al. (2006). Avaliação dos perfis de RAPD de diferentes partes do corpo de machos de abelhas Euglossa pleosticta Dressler (Hymenoptera: Apidae, Euglossina). Neotrop. Entomol. 35: 811-817. 
Pamponet VCC, Carneiro PLS, Affonso PRAM, Miranda VS, et al. (2008). A multi-approach analysis of the genetic diversity in populations of Astyanax aff. bimaculatus Linnaeus, 1758 (Teleostei: Characidae) from Northeastern Brazil. Neotrop. Ichthyol. 6: 621-630.

Phong DT, Hien VTT, Thanh TTV and Tang DV (2011). Comparison of RAPD and ISSR markers for assessment of genetic diversity among endangered rare Dalbergia oliveri (Fabaceae) genotypes in Vietnam. Genet. Mol. Res. 10: $2382-2393$.

Piorski NM, Sanches A, Carvalho-Costa LF, Hatanaka T, et al. (2008). Contribution of conservation genetics in assessing neotropical freshwater fish biodiversity. Braz. J. Biol. 68: 1039-1050.

Pritchard JK, Stephens M and Donnelly P (2000). Inference of population structure using multilocus genotype data. Genetics 155: 945-959.

Ramos JR, Telles MPC, Diniz-Filho JAF, Soares TN, et al. (2008). Optimizing reproducibility evaluation for random amplified polymorphic DNA markers. Genet. Mol. Res. 7: 1384-1391.

Ramos JVB, Sodré LMK, Orsi ML and Almeida FS (2012). Genetic diversity of the species Leporinus elongatus (Teleostei : Characiformes) in the Canoas Complex - Paranapanema River. Neotrop. Ichthyol. 10: 821-828.

Sanches A and Galetti Jr PM (2012). Population genetic structure revealed by a school of the freshwater migratory fish, Brycon hilarii. Lat. Am. J. Aquat. Res. 40: 408-417.

Sanches A, Galetti Jr PM, Galzerani F, Derazo J, et al. (2012). Genetic population structure of two migratory freshwater fish species (Brycon orthotaenia and Prochilodus argenteus) from the Sao Francisco River in Brazil and its significance for conservation. Lat. Am. J. Aquat. Res. 40: 177-186.

Slatkin M (1985). Gene flow in natural populations. Annu. Rev. Ecol. Syst. 16: 393-430.

Sofia SH, Silva CRM, Galindo BA, Almeida FS, et al. (2006). Population genetic structure of Astyanax scabripinnis (Teleostei, Characidae) from an urban stream. Hydrobiologia 553: 245-254.

Sofia SH, Galindo BA, Paula FM, Sodré LMK, et al. (2008). Genetic diversity of Hypostomus ancistroides (Teleostei, Loricariidae) from an urban stream. Genet. Mol. Biol. 1: 317-323.

Vianna NC and Nogueira MG (2008). Ichthyoplankton and limnological factors in the Cinzas River-an alternative spawning site for fishes in the middle Paranapanema River basin, Brazil. Acta Limnol. Bras. 20: 139-151.

Wasko AP and Galetti Jr PM (2002). RAPD analysis in the Neotropical fish Brycon lundii: genetic diversity and its implications for the conservation of the species. Hydrobiologia 474: 131-137.

Wright S (1978). Evolution and genetics of populations. 4th edn. The University of Chicago Press, Chicago. 